\title{
Prospects for the use of stone processing waste to obtain architectural and building ceramics
}

\author{
G.K. Voronov ${ }^{1}(0000-0003-1205-8608)$, A.I. Fesenko ${ }^{1}$ (0000-0003-3888-9493), \\ O.V. Savvova ${ }^{1}$ (0000-0001-6664-2274), S.O. Melnyk², O.P. Dehurko ${ }^{2}$ \\ 1 - O.M. Beketov National University of Urban Economy in Kharkiv, 17, Marshal Bazhanov Street, \\ Kharkiv, 61002, Ukraine \\ Tel.: +380577073101 \\ E-mail:voronov1976@ukr.net \\ 2 - D\&M Innovations LLC, 2, st. Korostyshevskaya, Bldg. 17G, Zhytomyr, 10001, Ukraine \\ Tel.: +380982684384; +380674126062 \\ E-mail:dm.ukrinnovation@gmail.com
}

Savvova, A.V., Ryabinin, S.A., Svetlichny, E.A., Voronov, G.K., Fesenko, A.I. (2019) Prospects for the use of stone processing waste to obtain architectural and building ceramics 4(45), doi: 10.26909/csl.4.2019.1

Article info: received 06.11.2019, revised 22.11.2019, accepted 06.12.2019

The article presents the results of a study of stone processing waste in order to justify the implementation of the technological process of manufacturing architectural and construction products with their use. The structure of the distribution of waste arising from stone processing processes is given. The analysis of the relevance of the problems of utilization of slurry waste stone processing. Studies were conducted to determine the chemical, mineralogical and phase composition of stone waste. It was found that these wastes belong to gabbro-diabase rocks, which was confirmed by their chemical and mineralogical composition. The main mineral components are plagioclase, pyroxene and minerals of the iron group. The moisture content of the initial pulp and the particle size distribution of dry sludge were determined. Based on the results of establishing the melting temperature and fire resistance of baked sludge samples, the possibility of obtaining architectural and construction products based on dry sludge using ceramic technology (semi-dry pressing and sintering) was established, for which a selection of technological parameters and initial mass compositions was carried out. The promising compositions of ceramic masses with a significant sludge content (up to $60 \%$ ), as well as the temperature-time regimes of the formation of ceramic materials, which are in the range from 1100 to $1200{ }^{\circ} \mathrm{C}$, are determined. The physicomechanical properties for sintered ceramic materials are studied, namely, mechanical strength compression (up to $55 \mathrm{MPa}$ ) and wear resistance (up to $0,45 \%$ ), which corresponds to the properties of clinker ceramic materials. Based on the foregoing, a conclusion was drawn on the prospects of using stone slurry for obtaining ceramic products for architectural and construction purposes.

Key words: architectural and construction products, stone processing, sludge, semi-dry pressing, physical and mechanical properties, clinker ceramics

\section{Перспективи використання відходів каменеобробки для одержання архітектурно-будівельної кераміки}

\author{
Г.К. Воронов ${ }^{1}$, О.І. Фесенко ${ }^{1}$ О.В. Саввова ${ }^{1}$, С.О. Мельник ${ }^{2}$, О.П. Дегурко² \\ 1 - Харківський національний університет міського господарства імені О.М. Бекетова, Харків, Україна \\ 2 - ТОВ «ДІМ ІННОВАЦІї», Житомир, Украӥна
}

У роботі наведені результати дослідження відходів каменеобробки з метою обгрунтування реалізації технологічного процесу виготовлення архітектурно-будівельних виробів з їх використанням. Наведено структуру розподілу відходів, що виникають при процесах каменеобробки. Проведено аналіз щодо актуальності проблем утилізації шламових відходів каменеобробки. Були проведені дослідження щодо визначення хімічного, 
мінералогічного та фазового складу відходів каменеобробки. Було встановлено, що дані відходи відносяться до габро-діабазових гірських порід, що було підтверджено їх хімічним та мінералогічним складом. Основними мінеральними складовими є плагіоклаз, піроксен та мінерали групи заліза. Проведено визначення вологості вихідної пульпи та гранулометричного складу сухого шламу. За результатами встановлення температури плавкості і вогнетривкості зразків спеченого шламу встановлено можливість отримання архітектурно-будівельних виробів на основі сухого шламу по керамічній технології (напівсухе пресування і спікання), для чого проведено підбір технологічних параметрів і вихідних складів мас. Визначені перспективні склади керамічних мас із значним вмістом шламу (до 60 \%), а також температурно-часові режими формування керамічних матеріалів, які знаходяться в діапазоні від 1100 до $1200{ }^{\circ} \mathrm{C}$. Досліджені фізико-механічні властивості для спечених керамічних матеріалів, а саме механічна міцність на стиск (до $55 \mathrm{MПа)} \mathrm{та} \mathrm{зносостійкість} \mathrm{(до} \mathrm{0,45} \mathrm{\% ),} \mathrm{що} \mathrm{відповідає} \mathrm{властивостям}$ клінкерних керамічних матеріалів. На підставі вищевказаного зроблено висновок щодо перспективності використання шламів каменеобробки для одержання керамічних виробів архітектурно-будівельного призначення.

\section{ВстуII}

В Україні щорічно видобувається більше десяти мільйонів тон твердих корисних копалин, близько 60 \% 3 яких після попередньої переробки потрапляють у відвали і хвостосховища. При цьому значну частку видобутку в гірничодобувній галузі забезпечує каменедобувна галузь. Ступінь утилізації відходів каменедобувної промисловості дуже низька і становить всього близько 10 \% від загального обсягу відходів. Залучення відходів каменевидобування та обробки каменю в виробництво $є$ дуже актуальним завданням у розрізі реалізації стратегії ресурсозбереження. Специфіка технологічних процесів отримання будівельних кам'яних виробів пов'язана 3 тим, що видобуток і обробка природного каменю носить багатоступінчастий характер, де послідовно виконуються кілька операцій (різання блоків, відкол, розпилювання, шліфування та полірування), тому більше половини видобутої гірничої маси в каменевидобування перетворюються у відходи.

Досягнення науково-технічного прогресу в області створення прогресивних технологічних способів переробки кам'яних відходів відкривають достатньо широкі можливості для ефективної переробки всієї видобутої гірничої маси облицювального каменю і значного скорочення втрат цієї мінеральної сировини.

На сьогодні актуальним питанням є розробки технологічних схем безвідходного виробництва на кар'єрах облицювального каменю з повною утилізацією всієї кам'яної маси. Це відповідає сучасним принципам економного витрачання невідновлюваних ресурсів природного облицювального каменю i охорони навколишнього середовища. Разом з тим необхідно відзначити, що технічні питання повної утилізації кам'яних відходів найглибше розроблені стосовно до гірських порід середньої твердості (мармуру, доломіту, травертину), відносно ж граніту, габро-діабазу і інших твердих порід технічні питання створення безвідходних виробництв знаходяться в самій початковій стадії розробки.
Враховуючи тенденції ресурсо- та енергозбереження й необхідність створення на основі відходів конкурентоспроможної продукції при виборі оптимальних технологій використання продукції слід орієнтуватися на одержання матеріалу 3 найменшою собівартістю (температурою та тривалістю термообробки). Це дозволить не лише розробити матеріал який буде утилізувати відходи, а й зробить даний продукт «привабливим» для виробника та споживача.

Нерудні корисні копалини є найбільш поширеними в світі як за кількістю їх видів, так і за кількістю відкритих і освоєних родовищ. Пояснюється це тим, що до них ставляться надзвичайно різні походження породи і мінерали. Нерудні копалини мають дуже широке застосування. Вони застосовуються в промисловості, також вони використовуються в будівництві, науці і техніці, побуті та медицині.

Україна $\epsilon$ країною 3 величезними природно-кам'яними ресурсами. На території України розвідано понад 300 родовищ облицювального каменю 3 промисловими запасами близько 500 млн. м³. Майже половина родовищ граніту знаходиться в експлуатації. Більшість родовищ геологічно пов'язано 3 «українським кристалічним щитом». Протяжність «українського кристалічного щита»: від узбережжя Азовського моря в північно-західному напрямку до кордону з Білоруссю, майже на 1000 км. Ширина його разом зі схилами змінюється від 150 до 450 км, площа в контурах виходів докембрійських утворень складає 136,5 тис. км², а загальна площа з урахуванням схилів - 256,6 тис. км². Український щит займає більше третини території країни.

Значною складовою частиною українського кристалічного щита є Житомирський гірський щит, який знаходиться на території Коростенського плутону - одного з найбільших масивів інтрузивних порід на північному заході Українського щита, і має загальну площу близько 10 тис. км². Коростенський плутон складається 3 порід двох складів - кислого та основного. Для порід кислого складу, таких як граніт, характерний високий вміст заліза в темноко- 
льорових мінералах. За мінерально-петрографічними особливостям гібридні породи Коростенського плутону займають проміжне положення між гранитоїдами і габброїдами. Основні породи, до яких відносяться габро, габро-норити та лабрадорити, займають майже четверту частину його площі та утворюючи чотири масиви (Володарсько-Волинський, Чоповічський, Федоровський i Кривогінський) i кілька менших областей, лише частково розкритих чи ще не розкритих ерозією (Могилянська, Лугинська, Полчанская та ін.) $[1,2]$.

Як правило, природні кам'яні матеріали отримують шляхом механічної обробки скельних гірських порід. При цьому руйнується монолітність вихідної сировини і частково його структура. В основі класифікації природних кам'яних матеріалів лежить технологія їх виробництва.

При виборі методу видобутку враховують місцеві умови, вид породи, глибину і характер іiі залягання. Розробка гірської породи в залежності від умов залягання може бути відкрита або підземна. Видобуток твердих масивних гірських порід ведеться буро-підривним способом, менш тверді шаруваті і тріщинуваті породи розробляються буро-клиновим i ударо-клиновим способами. М'які породи розпилюють на блоки правильної геометричної форми спеціальними каменерізними машинами безпосередньо на місці залягання породи. Машини особливо ефективні при підземних виробках слабких і м'яких порід, наприклад черепашнику, вапняних туфів і т.п. Більш тверді породи (мармур, граніти) розпилюють на штучний камінь, блоки та плити пилами зі сталевими дисками, армованими пластинками твердих сплавів або з абразивними порошками.

Через специфіку технологічних процесів отримання облицювальних кам'яних виробів, де продукція повинна мати прямокутну форму, більше половини видобутої гірничої маси в каменевидобування перетворюються у відходи (рис. 1). Це пов'язано 3 тим, що видобуток і обробка природного каменю носить багатоступінчастий характер, де послідовно

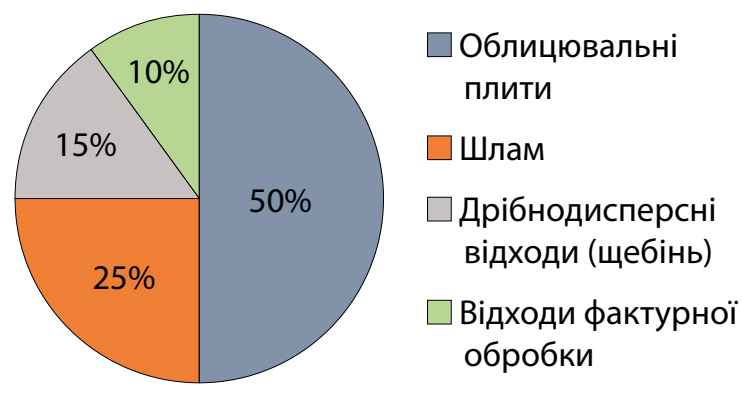

Рис. 1. Структура розподілу відходів при добуванні кам'яних блоків виконуються кілька операцій (формування блоків різанням або буро-підривними роботами, відкол $\mathrm{i}$ навантаження, розпилювання в великі плити, розпилювання в більш дрібні плити, окантовка, шліфування та полірування).

Ступінь утилізації відходів каменедобувної промисловості дуже низька і становить всього близько $10 \%$ від загального обсягу відходів. Як видно з статистичних даних найбільш значну частку відходів каменеобробки становлять шлами - вони $є$ найбільш активними і екологічно шкідливими відходами каменеобробних підприємств, а рівень їх утилізації вкрай низький. Головним чином це тонкодисперсні шлами (частки менш 10 - 40 мкм) силікатного складу, що є відходом обробки гірських порід групи гранітів (граніту, сиєніту, діабазу, габро, лабрадориту), тому не вимагають додаткового подрібнення. Ці породи містять в своєму складі мінерали (кварц, польові шпати та ін.), що застосовуються в технології архітектурно-будівельної кераміки в якості компонентів керамічних мас (отощувачі, плавні та інш.) А оскільки шлам являє собою суспензію силікатних відходів у воді, це може полегшити процес його гомогенізації при змішуванні з іншими сировинними компонентами. Сухі шлами можуть бути застосовані як наповнювачі бетонів, сухих будівельних сумішей та як компоненти кислотостійких замазок при виконанні антикорозійних робіт у будівництві та хімічному машинобудуванні.

\section{Матеріали та методи дослідження}

Метою роботи є дослідження перспективи використання відходів каменеобробки, а саме тонкодисперсних шламів 3 метою реалізації технологічного процесу виготовлення архітектурно-будівельних виробів на їх основі зі значною долею їх використання при виробництві. Зразками для дослідження були шламові відходи видобутку гірських порід Житомирського щита, що використовувалися в якості сировини для отримання архітектурних (декоративних та оздоблювальних) виробів.

Першочерговим напрямком роботи було дослідження рідких відходів каменеобробки, а саме: визначення вологості вихідної сировини (шламу); визначення хімічного та гранулометричного складу сухого шламу; встановлення інтервалу плавкості і вогнетривкості зразків спеченого шламу.

Другим етапом роботи було вивчення можливості отримання архітектурних виробів на основі сухого шламу за керамічною технологією напівсухого пресування і спікання - підбір вихідних складів мас і технологічних параметрів термообробки, а також визначення фізико-механічних властивостей на одержаних зразках. 
Дослідження структури зразків проводилось на оптичному мікроскопі Bresser LCD Micro 40x-1600x. Визначення вогнетривкості проб матеріалів з ідентифікаційними номерами здійснювали інструментальним методом у відповідності до ГОСТ 4069-69.

Для виготовлення зразків методом пресування помел компонентів мас проводили у планетарному млині Retsch PM-400. Для пресування зразків використовували лабораторний гідравлічний прес 3 максимальним навантаженням $\mathrm{P}=24,5 \mathrm{MПа}$. Водопоглинення визначали методом гідростатичного зважування з використанням установки для насичування зразків рідиною у вакуумі. Визначення дійсної щільності отриманих матеріалів здійснювали пікнометричним методом за ГОСТ 2211-65; уявну щільність та відкриту пористість встановлювали за ГОСТ 2409-95 (ISO 5017-88). Для проведення досліджень зносостійкості зразків керамічних матеріалів використовували коло стирання типу ЛКИ-3.

Дослідження иламу каменеобробки. Визначення вологості шламу, гранулометричного та мінерально-петрографічного складу, проводили за ГОСТ 8735-88. Вихідний зразок шламу гомогенізували та методом квартування відбирали пробу масою 100 г. Для повторюваності результатів вимірювання було підготовлено 3 проби шламу.

\section{Результати та їх обговорення}

Результати визначення вологості наведені в табл. 1.

Середня вологість шламу каменеобробки склала $\approx 27 \%$.
Для визначення гранулометричного складу, мінерально-петрографічного і хімічного аналізів були відібрані лабораторні проби з вагою від $50 \div 100$ г.

Визначення гранулометричного складу сухого шламу проводили методом ситового аналізу, результати якого наведені в табл. 2.

За даними аналізу більшість фракційного складу сухого шламу складають частки 3 розміром до 63 мкм.

Результати хімічного аналізу дослідних зразків кускових порід і сухого шламу каменеобробки одержані рентгеноспектральним методом на рентгенівському спектрометрі PANalytical Axios max. Результати аналізу наведені в табл. 3.

Дані мінерально-петрографічного аналізу зразків шламу показали, що він відповідає мінеральному складу базових порід - габро-діабазів. Це підтверджується даними оптичної мікроскопії (табл. 4). Основними мінеральними складовими якого є (у мас. \%): плагіоклаз - до 53; піроксен - до 34; титано-магнетит - до 7; маггеміт, гематит - до 4,5; амфібол - до 4,5; олівін - до 2; кварц - до 1; нефелін - до 1; мусковіт - до 1,5.

Для оцінки інтервалу спікання шламу та визначення його придатності для термообробки було проведено визначення його вогнетривкості (рис. 2).

Як видно з результатів випробування дослідні конуси схилилися однаково за температури $1130{ }^{\circ} \mathrm{C}$. Тобто ця температура $є$ температурою наявності рідкої фази у складі матеріалу.

Одержання зразків керамічних виробів на основі шламу. За даними наукової літератури та за даними

Таблиця 1.

Вологість шламу каменеобробки

\begin{tabular}{|c|c|c|c|c|}
\hline \multirow{2}{*}{ Зразок } & \multicolumn{2}{|c|}{ Маса зразку } & \multirow{2}{*}{$\begin{array}{c}\text { Вологість зразку, } \\
\text { W, \% }\end{array}$} & \multirow{2}{*}{$\begin{array}{c}\text { Середня вологість } \\
\text { зразку, } \mathrm{W}_{\mathrm{cp}}, \%\end{array}$} \\
\hline & початкова, $\mathrm{m}_{\text {н }}$, г & кінцева, $\mathrm{m}_{\mathrm{H}}$, г & & \\
\hline 1 & 100,00 & 73,07 & 26,93 & \multirow{3}{*}{27,01} \\
\hline 2 & 100,00 & 73,11 & 26,89 & \\
\hline 3 & 100,00 & 72,80 & 27,20 & \\
\hline
\end{tabular}

Таблиця 2.

Гранулометричний склад сухого шламу

\begin{tabular}{|c|c|c|}
\hline Розмір фракцій, мкм & Вага, г & Вміст, $\%$ \\
\hline$>150$ & 0,2 & 0,20 \\
\hline $121-150$ & 1,9 & 1,93 \\
\hline $71-121$ & 25,1 & 25,43 \\
\hline $63-71$ & 6,8 & 6,89 \\
\hline$<63$ & 64,7 & 65,55 \\
\hline Сумма, $\Sigma$ & 98,7 & 100 \\
\hline
\end{tabular}



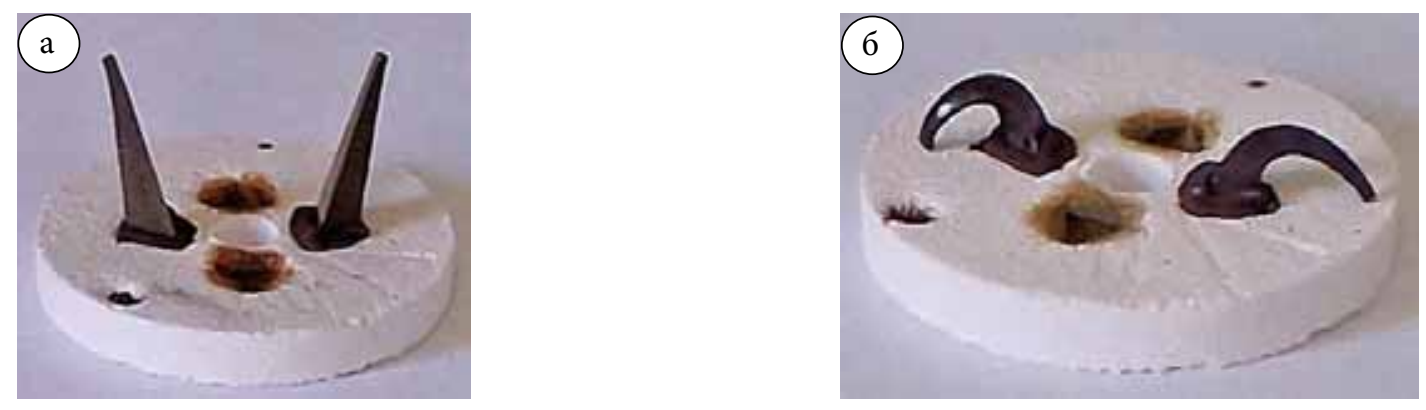

Рис. 2. Зовнішній вигляд конусів (випробних зразків), виготовлених із проби сухого шламу: а - конуси до випробовування; б - конуси після випробовування

Таблиця 3.

Хімічний склад сухого шламу каменеобробки

\begin{tabular}{|c|c|c|c|c|c|c|c|}
\hline \multicolumn{7}{|c|}{ Вміст компонента у складі матеріалу, мас. \% } \\
\hline $\mathrm{SiO}_{2}$ & $\mathrm{Al}_{2} \mathrm{O}_{3}$ & $\mathrm{Fe}_{2} \mathrm{O}_{3}$ & $\mathrm{CaO}$ & $\mathrm{MgO}$ & $\mathrm{Na}_{2} \mathrm{O}$ & $\mathrm{K}_{2} \mathrm{O}$ & $\mathrm{TiO}_{2}$ \\
\hline 47,01 & 13,7 & 17,58 & 8,59 & 4,23 & 3,07 & 1,57 & 3,39 \\
\hline $\mathrm{MnO}$ & $\mathrm{ZnO}$ & $\mathrm{BaO}$ & $\mathrm{SrO}$ & $\mathrm{ZrO}_{2}$ & $\mathrm{WO}_{3}$ & $\mathrm{SO}_{3}$ & в.п.п. \\
\hline 0,25 & 0,02 & 0,064 & 0,035 & 0,037 & 0,034 & 0,32 & 0,123 \\
\hline
\end{tabular}

Таблиця 4.

Мікроскопічний аналіз мінеральних складових шламу

\begin{tabular}{|c|c|}
\hline Мінеральна складова & Мікрофотографія зразка \\
\hline $\begin{array}{l}\text { Ортопіроксен } \\
\text { Розмір зерен від } 0,5 \text { до } 3 \text { мм } \\
\text { Зміст ортопіроксену близько } 30 \%\end{array}$ & \\
\hline $\begin{array}{l}\text { Амфіболізіровані піроксеніти, що складаються з агрегату ідіоморф- } \\
\text { них кристалів клинопіроксену (60 \%), рогової обманки }(7-10 \%) \text { i } \\
\text { тонковолокнистих актінолітових утворень }\end{array}$ & \\
\hline $\begin{array}{l}\text { Амфібол-плагіоклазове габро } \\
\text { Різновиди польовошпатових порід, що утворені ідіоморфним плагі- } \\
\text { оклазом ( } 65 \text { - } 70 \text { \%), бурою рогової обманкою і кварцом в кількостях, } \\
\text { що не перевищують } 10 \%\end{array}$ & \\
\hline
\end{tabular}


хімічного та мінералогічного складу шламових відходів каменеобробки встановлено, що вони не містять в'яжучих компонентів, тому практично неможливо одержання архітектурних виробів на основі чистого відходу [3]. Але одною з головних цілей роботи був пошук можливості застосування максимальної кількості шламу у складі готового виробу. Тому доцільним є додавання до сухої пульпи компонентів, що сприятимуть зміцненню структури готових виробів. Краще всього підходить глина, як матеріал, що покращує експлуатаційні властивості при пресуванні, а також при спіканні виробів з відходів каменеобробки.

Була складена серія складів мас з вмістом шламу від 50 до 80 мас. \% для виробів, які будуть одержані методами пресування та спікання.

Вироби з вказаних складів готувалися методом двостадійного пресування на лабораторному гідравлічному пресі при максимальному тиску пресування 15 - 17 МПа. Відпресовані вироби проходили сушку до остаточної вологості не більш 2 \% при температурі $120-140{ }^{\circ} \mathrm{C}$.

Випал сухих виробів проводили в лабораторній електричній печі при температурах від 1100 до $1250{ }^{\circ} \mathrm{C}$. Час витримки при максимальній температурі випалу становив від 30 до 60 хвилин в залежності від маси зразку.

Зовнішній вигляд випалених зразків наведений на рис. 3.

Колір виробів змінювався в залежності від температури випалу (в більшій мірі) та часу випалу (в меншій мірі). Зміна кольору виробів пов'язана 3 кристалізацією та виходом забарвлюючих фаз заліза, яке в значної кількості міститься у складі сировини.
Спечені керамічні вироби мають відповідну залежність водопоглинання від збільшення температури випалу (рис. 4). Завдяки появі рідкої фази в процесі випалу матеріалу, що обумовлюється значним вмістом в сировині відносно легкоплавких мінеральних компонентів - плагіоклазу та піроксену, відбувається різке ущільнення керамічної маси.

Мінімальний показник має зразок одержаний при температурі випалу $1200{ }^{\circ} \mathrm{C}$. Показник його водопоглинання до 5 \% відповідає вимогам щодо клінкерних керамічних матеріалів (клінкерна цегла та плитка).

Дослідження механічної міцності (за міцністю на стиск) та зносостійкості одержаних зразків керамічних матеріалів на основі шламу каменеобробки також показали чітку залежність вказаних показників від температури термообробки заготовок (рис. 5).

Показники механічної міцності спечених матеріалів, що одержані при температурах вище $1100{ }^{\circ} \mathrm{C}$ за своїми показниками перевищують вимоги до керамічної цегли та цілком відповідають вимогам до клінкерної кераміки. Також видно, що при тих же самих температурах різко змінюється зносостійкість зразків, що теж пов'язано з ущільненням матеріалу у процесі випалу.

\section{Висновки}

В роботі були проведені дослідження особливостей структури та складу шламу каменеобробки, як перспективного сировинного матеріалу для керамічної технології. Визначені можливі состави керамічних мас із значним вмістом шламу (до $60 \%$ ), а також температурно-часові режими формування

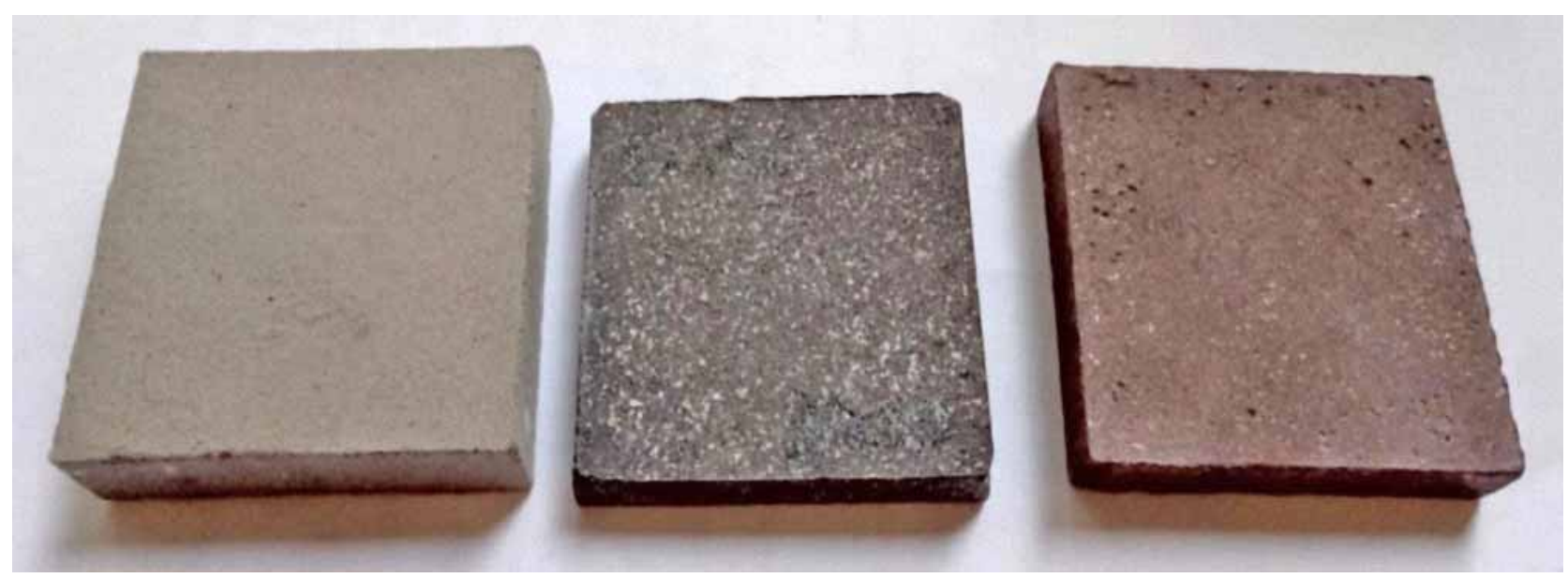

Рис. 3. Зовнішній вигляд випалених керамічних виробів 


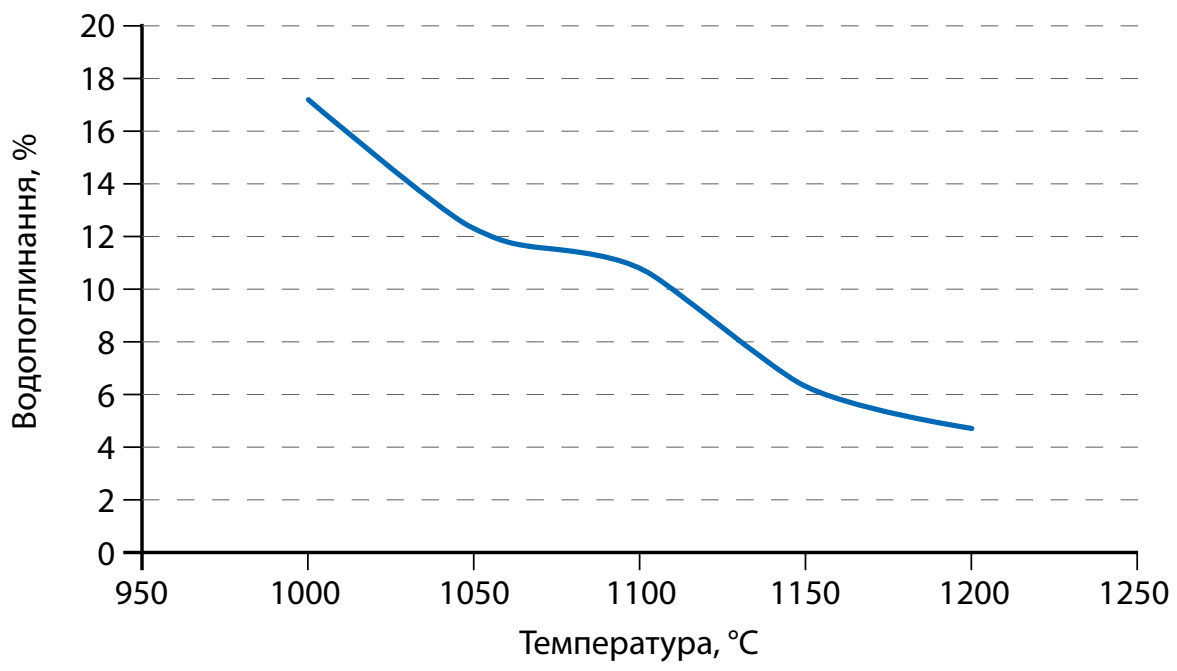

Рис. 4. Залежність водопоглинання спечених керамічних матеріалів від температури

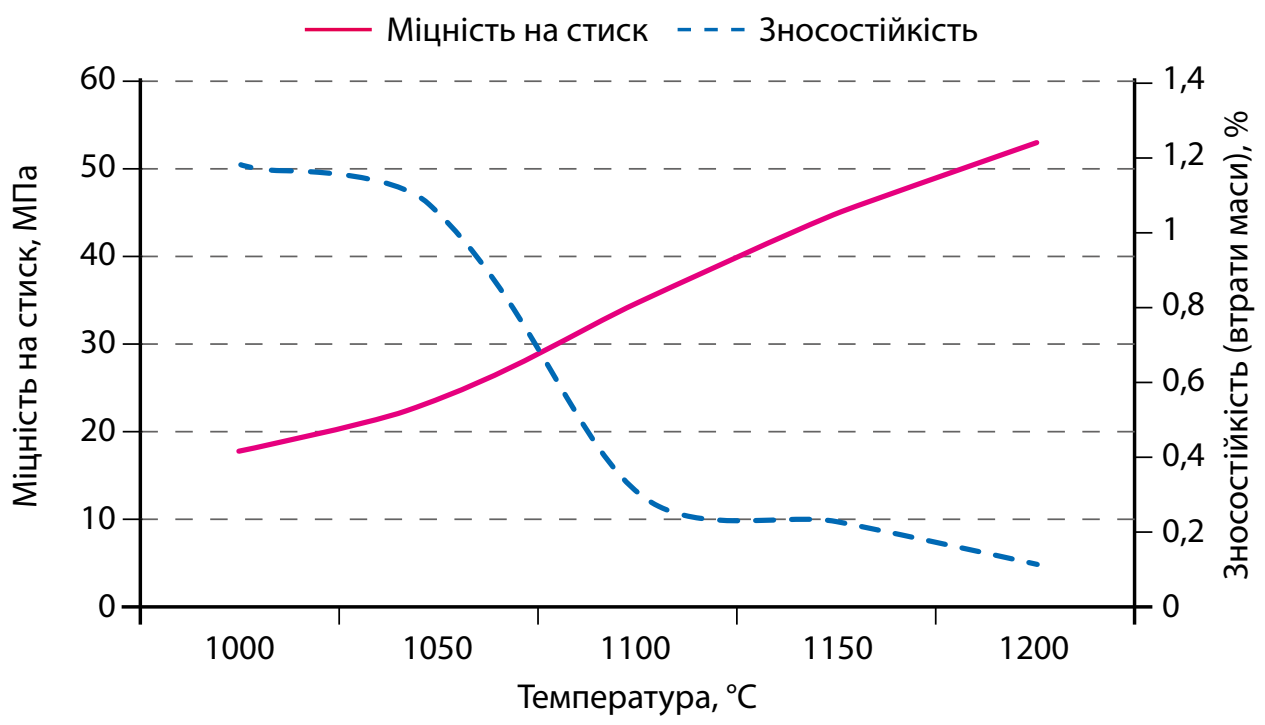

Рис. 5. Залежність механічної міцності та зносостійкості спечених керамічних матеріалів від температури

керамічних матеріалів. Досліджені фізико-механічні властивості для спечених керамічних матеріалів. Можна вважати, що оптимальним режимом термообробки для керамічних матеріалів на основі шламового відходу буде температурний діапазон від 1100 до $1200{ }^{\circ} \mathrm{C}$. Час випалу буде визначатися масою зразку та типом теплотехнічного агрегату.

За результатами проведених досліджень можна зробити висновок щодо перспективності використання шламів каменеобробки для одержання керамічних виробів архітектурно-будівельного призначення.

\section{References}

1. Митрохин, A.B. Петрология "гибридных пород" Коростенского плутона анортозит-рапакивигранитной формации украинского щита / А.В. Митрохин, Е.В. Билан // Mineral. Journ. - 2014. - Т. 36, № 2. - С. 102 - 118 .

2. Личак, И.Л. Петрология Коростенского плутона. - К.: Наук. Думка. - 1983. - 246 с.

3. Попов, К.Н., Каддо, М.Б. Строительные материалы и изделия. - М: Высш. шк. - 2002. - 367 с. 